\title{
Decolorization of the phthalocyanine dye reactive blue 21 by turnip peroxidase and assessment of its oxidation products
}

\author{
Maria Cristina Silva ${ }^{\mathrm{a}, *}$, Angelita Duarte Corrêa ${ }^{\mathrm{a}}$, Maria Teresa Sousa Pessoa Amorim ${ }^{\mathrm{b}}$, Píer Parpot ${ }^{\mathrm{c}}$, \\ Juliana Arriel Torres ${ }^{a}$, Pricila Maria Batista Chagas ${ }^{a}$ \\ a Federal University of Lavras, Department of Chemistry, 37200-000, Lavras, MG, Brazil \\ b University of Minho, Department of Textile Engineering, 4800-058 Guimarães, Portugal \\ c University of Minho, Department of Chemical, 4710-057, Braga, Portugal
}

\section{A R T I C L E I N F O}

\section{Article history:}

Received 28 June 2011

Received in revised form 23 October 2011

Accepted 12 December 2011

Available online 20 December 2011

\section{Keywords:}

Environmental biocatalysis

LC-ESI/MS

Turnip peroxidase

Decolorization

Textile dyes

\begin{abstract}
A B S T R A C T
Peroxidases can be used in decolorization processes and the treatment of textiles effluents. This study evaluates the potential of the turnip peroxidase enzyme in the decolorization of the phthalocyanine textile dye Reactive Blue 21 (RB21). Some factors such as pH, the amount of $\mathrm{H}_{2} \mathrm{O}_{2}$ and the enzyme were evaluated in order to determine the optimum conditions for the enzyme performance. The reaction products formed during the decolorization of the RB21 dye were analyzed by high-performance liquid chromatography-mass spectrometry coupling (LC-ESI/MS). LC-ESI/MS analysis showed that the decolorization of the dye RB21 by turnip peroxidase is due to the breaking up of the chromatogenous system. The tests for toxicity towards lettuce seeds showed an increase of the toxicity after enzymatic treatment of the dye. This study verifies the viability of the use of the turnip peroxidase enzyme in the biodegradation of textile dyes.
\end{abstract}

(C) 2011 Elsevier B.V. All rights reserved.

\section{Introduction}

The removal of dyes from textile wastewater prior to its discharge or reuse is a challenging task. The presence of color hinders the absorption of solar radiation, which can modify photosynthetic activity, causing changes in aquatic biota. Moreover, many of these dyes present acute or chronic toxicity on the ecosystems [1].

Unfortunately, the exact data on the quantity of dyes produced in the world or discharged in the environment are not available. It is assumed a production of 10,000 tons per year, while a loss of $1-2 \%$ in production and $1-10 \%$ loss in use are a fair estimate [2].

Phtalocyanine (PC) dyes are among the dyes which resist to bacterial degradation. These dyes constitute the main category of the reactive dyes which are one of the most important class of textile dyes [3].

Phthalocyanine reactive dyes are metallic complexes used to produce blue and green shades. Most of these dyes are copper phthalocyanines. They are potentially mutagenic and of special toxicity concern because of their metal Cu content [4].

\footnotetext{
* Corresponding author. Tel.: +55 32 88736085; fax: +55 3538291628

E-mail addresses: crisiria@yahoo.com.br (M.C. Silva), angelita@dqi.ufla.br (A.D. Corrêa), mtamorim@det.uminho.pt (M.T.S.P. Amorim), parpot@quimica.uminho.pt (P. Parpot).
}

The inherent properties of reactive phthalocyanine dyes, such as color fastness, stability, and resistance towards oxidative degradation, have made color removal from textile wastewaters a particularly difficult task. Reactive phthalocyanine dyes are highly water-soluble, resistant to biological degradation under aerobic conditions, and are not effectively removed by adsorption to the biomass in wastewater treatment plants, resulting in colored effluents [4].

Researchers have been focusing their attention to study enzymatic pretreatment as a potential and viable alternative to conventional methods, due to its highly selective nature [5-7]. Enzymes can act on specific recalcitrant pollutants to be removed by their precipitation or transformation into other innocuous products $[8,9]$.

The removal of phthalocyanines dyes in aqueous solution by peroxidase has been widely reported, in last years, especially by white-rot fungi. Peroxidases can catalyze degradation/transformation of aromatic dyes either by precipitation or by opening the aromatic ring structure [10].

The decolorization of two reactive PC dyes, Reactive blue 15 (RB15) and Reactive blue 38 (RB38), by Bjerkandera adusta, Trametes versicolor and Phanerochaete chrysosporium was shown by Heinfling et al. [11]. Meanwhile, the PC dye RB21 (Reactive Blue 21) was oxidized by Horsehadish peroxidase. The decolorization of the dye RB21 in this case was approximately 59\% [12]. The degradation of dye RB21 was also evaluated by Marchis et al. [13], using soybean 


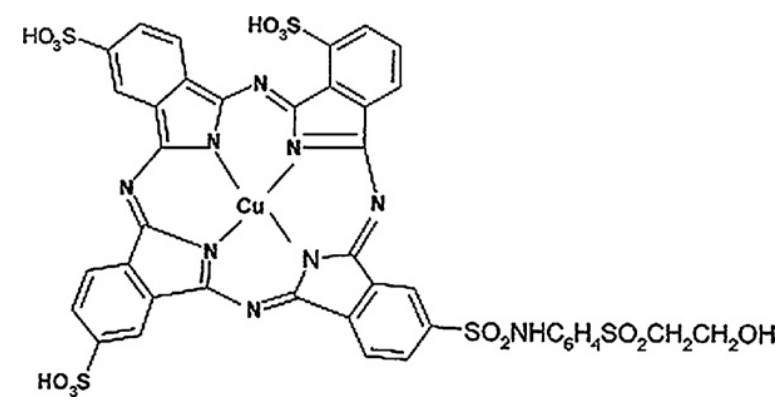

Fig. 1. The molecular-structure of reactive blue 21 dye.

peroxidase as biocatalyst. The decolorization obtained was $95-96 \%$ after $4 \mathrm{~h}$ of reaction at $\mathrm{pH}$ 3.0.

Despite these previous investigations have shown that PC dyes can be decolorized by white-rot fungi or by plant peroxidases, the degradative pathway and potential metabolites, mostly, remain unknown. The knowledge of the metabolites formed during the decolorization of textile dyes by plant peroxidases is a way for the understanding of the break up mechanism of complex structures chemically stable, by the enzymes [11].

Many treatments can be efficient in the decolorization, but it is essential to know if there is formation of toxic products during the process. A valuable technique to evaluate the toxicity of the reaction products is the use of bioindicators [14].

In general it becomes very important for a bioremediation technology to assess the toxicity of the pollutants and metabolites formed after their degradation in order to test out the feasibility of the technique [15].

There are few studies to assess the toxicity of dyes and the products formed during their enzymatic degradation. Da Silva and coworkers [16] observed the reduction of Artemia salina mortality after decolorization reactions of Drimarene Blue X-3LR (DMBLR), Drimarene Rubinol X-3LR (DMR), and Drimarene Blue CL-R (RBBR) by horsehadish peroxidase.

The metabolites formed after degradation of remazol red by Pseudomonas aeruginosa $\mathrm{BCH}$ were more toxic than the parental molecule [15].

In this work study, the use of the turnip peroxidase in the decolorization of the PC dye RB21 is studied. In this context, the effect of parameters such $\mathrm{H}_{2} \mathrm{O}_{2}$, dye and enzyme concentrations, as well as contact time has been investigated to optimize the system conditions. The toxicity of the dye both before and after the enzymatic dye was evaluated by utilizing lettuce seeds (Lactuca sativa) as a bioindicator.

Moreover, we here report the identification of the major metabolites of the treatment of the PC dye RB21 with turnip peroxidase by liquid chromatography-mass spectrometry (HPLC-MS).

\section{Material and methods}

\subsection{Dye}

The textile dye RB21 was kindly provided by DyStar (Brasil) and were used for degradation experiments without any further purification. The molecular-structure of the dye is shown in Fig. 1 [17].

\subsection{Obtention of the enzymatic extract}

The enzyme was extracted from turnip roots purchased from local market. The roots (with peel) were washed in water and cut into small uniform pieces. Turnip roots $(300 \mathrm{~g})$ were homogenized in a blender with $100 \mathrm{~mL}$ of $0.05 \mathrm{~mol} \mathrm{~L}^{-1} \mathrm{pH} 6.5$ phosphate buffer for $30 \mathrm{~s}$. The homogenate was filtered in organza cloth and centrifuged at $10,000 \times \mathrm{g}$ for $15 \mathrm{~min}$, at $4^{\circ} \mathrm{C}$ [18]. The obtained solution was subjected to precipitation by adding cold acetone until reaching $65 \%(\mathrm{v} / \mathrm{v})$. After a rest from 12 to $14 \mathrm{~h}$, at $-18^{\circ} \mathrm{C}$, the homogenate was centrifuged at $11,000 \times \mathrm{g}$ for $15 \mathrm{~min}$, at $4^{\circ} \mathrm{C}$. The supernatant was collected and acetone was subsequently recovered by distillation in a rotary evaporator, at controlled temperature of $56^{\circ} \mathrm{C}$. The obtained precipitate after the removal of the acetone by a treatment in gridge during $72 \mathrm{~h}$ was redissolved in $15 \mathrm{~mL}$ sodium phosphate buffer, pH 6.5 and then used in the dye removal studies.

\subsection{Determination of enzyme activity}

The activity was determined according to Khan and Robinson [19], using as reaction medium: $1.5 \mathrm{~mL}$ of guaiacol (Vetec; $97 \%, \mathrm{v} / \mathrm{v}$ ) $1 \%(\mathrm{v} / \mathrm{v}) ; 0.4 \mathrm{~mL}$ of $\mathrm{H}_{2} \mathrm{O}_{2}$ (Vetec, PA) $0.3 \%(\mathrm{v} / \mathrm{v}) ; 0.1 \mathrm{~mL}$ of enzyme and $1.2 \mathrm{~mL}$ of $0.05 \mathrm{~mol} \mathrm{~L}^{-1}$ phosphate buffer $\mathrm{pH}$ 6.5. The reaction was monitorized during $5 \mathrm{~min}$ at $30^{\circ} \mathrm{C}$ using a Spectrovision spectrophotometer coupled to a thermostatic bath.

One unit of peroxidase activity represents the oxidation of $\mu \mathrm{mol}$ of guaiacol during $1 \mathrm{~min}$ in the assay conditions and it was calculated using data relative to the linear portion of the curve.

\subsection{Dye removal studies}

Experiments were conducted to assess the turnip peroxidase catalyzed removal of phthalocyanine dye in aqueous phase. The experiments were carried out at a constant temperature $\left(30^{\circ} \mathrm{C}\right)$ by varying the process parameters such as dye, $\mathrm{H}_{2} \mathrm{O}_{2}$ and enzyme concentrations [20]. Initially the enzymatic reactions were conducted in sodium phosphate buffer, $0.05 \mathrm{~mol} \mathrm{~L}^{-1}$, pH $7.0(1.2 \mathrm{~mL})$, containing: (1) $\mathrm{H}_{2} \mathrm{O}_{2} 100 \mu \mathrm{mol} \mathrm{L}^{-1}(0.4 \mathrm{~mL})$, (2) the dye Remazol Turquoise $\mathrm{G} 133 \%$, at concentration of $50 \mathrm{mg} \mathrm{L}^{-1}(1.5 \mathrm{~mL})$ and $0.1 \mathrm{~mL}$ of enzymatic solution for estimated the optimum contact time.

The reaction mixture was incubated in a spectrophotometer coupled to a thermostatic bath. The monitorization of the substrate consumption was carried out at $624 \mathrm{~nm}$ which corresponds to the maximum absorption of Remazol Turquoise G 133\%. The calculation to determine the color removal percentage of the dyes was made according to the equation:

$\frac{\text { absorbancy }_{\text {initial }}-\text { absorbancy }_{\text {final }}}{\text { absorbancy }_{\text {initial }}} \times 100$

Subsequent series of experiments were performed by varying the concentrations of dye concentration (from 10 to $50 \mathrm{mg} \mathrm{L}^{-1}$ ), $\mathrm{H}_{2} \mathrm{O}_{2}$ dose (from 50 to $500 \mu \mathrm{mol} \mathrm{L}^{-1}$ ) and enzyme concentration (from 1.62 to $26.16 \mathrm{U} \mathrm{mL}^{-1}$ ) to understand the optimum conditions for dye removal. Reactions were performed also using multiple or single additions of $\mathrm{H}_{2} \mathrm{O}_{2}$.

\subsection{HPLC-MS}

The HPLC-MS analyses were performed using a liquid chromatographic system (Thermo Surveyor with gradient pump, auto sampler and diode array detector - DAD) coupled to a mass spectrometer Thermo LXQ Linear Ion Trap with electrospray ionization (ESI+) and a diode array detector.

The samples were filtered through ultrafiltration membranes (Millipore) with molecular weight cut $50 \mathrm{kDa}$, before injection into the chromatograph.

A volume of $20 \mu \mathrm{L}$ of sample was injected and the chromatographic separation was performed on a Hypersil GOLD column $(100 \mathrm{~mm} \times 4.6 \mathrm{~mm})$. Methanol/water (acidified $1 \%$, v/v) was used as mobile phase at a flow rate of $0.4 \mathrm{~mL} \mathrm{~min}^{-1}$. 


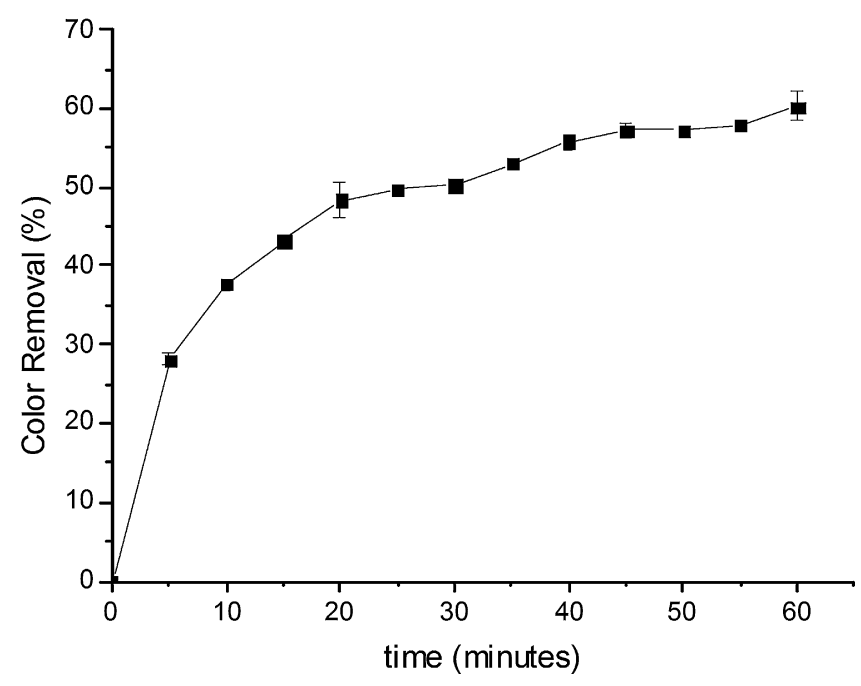

Fig. 2. Effect of reaction time on the decolorization of RB21 by turnip peroxidase.

\subsection{Acute toxicity test with L. sativa}

The lettuce seed root growth inhibition test was performed with 20 seeds in a polystyrene Petri dish, containing a filter paper embedded in $2 \mathrm{~mL}$ of each sample dilution (100, 75, 50, and 25\%). Root lengths were measured after $72 \mathrm{~h}$ and the $\mathrm{LC}_{50}$ was calculated [21]. The samples used consisted of the dye before and after enzymatic treatment and, as negative control, distilled water. Controls were carried out in parallel using only a $\mathrm{Cu}^{2+}$ solution at the concentration of $0.037 \mu \mathrm{mol} \mathrm{mL}{ }^{-1}\left(\mathrm{Cu}^{2+}\right.$ content theoretical for $\mathrm{RB} 21$ $\left.40 \mathrm{mg} \mathrm{L}^{-1}\right)$. The tests were carried out in triplicate.

\section{Results and discussion}

\subsection{Decolorization of RB 21 dye by turnip peroxidase}

In this paper, the parameters were optimized separately (reaction time, dye concentration, quantity of $\mathrm{H}_{2} \mathrm{O}_{2}$ and quantity of enzyme), to obtain the maximum decolorization of the dye.

\subsubsection{Optimum contact time}

The efficiency of the decolorization of the RB 21 dye as a function of contact time with the enzyme, is given in Fig. 2. The decolorization was $57.00 \pm 0.45 \%$ in 50 min of contact with enzyme. After $50 \mathrm{~min}$ of reaction, the dye removal became negligible. Souza et al. [12] have reported that $45 \mathrm{~min}$ is the reaction time required to catalyzed the degradation of the RB 21 dye, with decolorization of $59 \%$ by HPR. Subsequent experiments were performed for $50 \mathrm{~min}$ of reaction time.

\subsubsection{Optimum concentration of $\mathrm{H}_{2} \mathrm{O}_{2}$}

Hydrogen peroxide acts as a co-substrate to activate the enzymatic action of peroxidase radical. However, the excess of this reagent in the reaction inhibits the enzyme activity and, when present in small quantity, limits the reaction rate [20-22]. It was observed in Fig. 3 that the peroxide concentration of $100 \mu \mathrm{mol} \mathrm{L}^{-1}$ showed a better enzyme performance $(55.1 \pm 0.75 \%$ of decolorization).

The concentration of peroxide in the reaction showed no significant influence on the efficiency of color removal. However for concentrations above $200 \mu \mathrm{mol} \mathrm{L}^{-1}$ takes place an inhibitory effect.

Multiple $\mathrm{H}_{2} \mathrm{O}_{2}$ additions provide a low effective concentration of peroxide in reaction medium, avoiding the loss of enzyme activity [23]. Therefore, after $30 \mathrm{~min}$ of the oxidation reaction a second

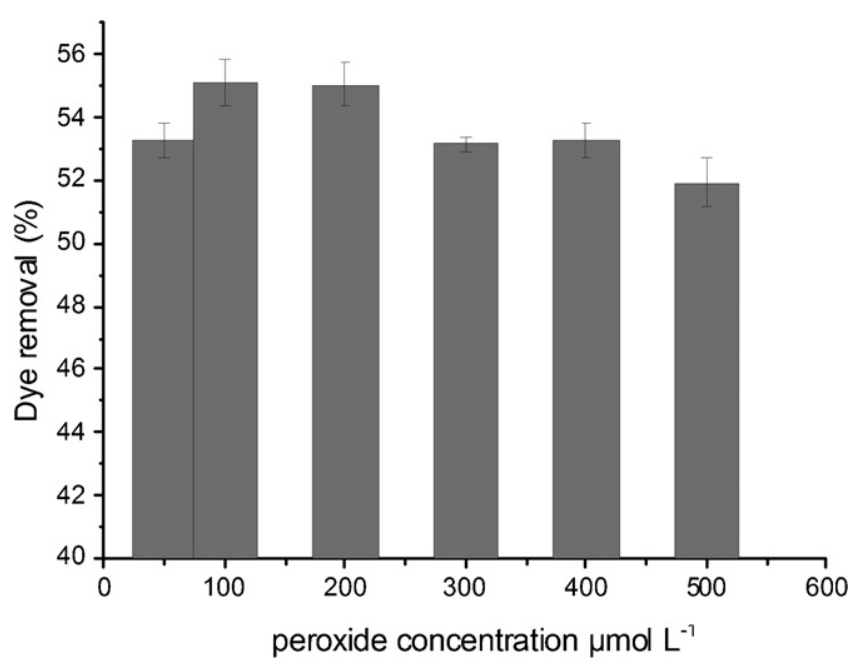

Fig. 3. Effect of $\mathrm{H}_{2} \mathrm{O}_{2}$ dose on the decolorization of $\mathrm{RB} 21$ by turnip peroxidase.

portion of $\mathrm{H}_{2} \mathrm{O}_{2}$ was added, so that in the end, the reagent concentration was $100 \mu \mathrm{mol} \mathrm{L}^{-1}$. The percentage for color removal after multiple addition of $\mathrm{H}_{2} \mathrm{O}_{2}$ in reaction was $57 \pm 0.83 \%$, demonstrating that the concentration of $\mathrm{H}_{2} \mathrm{O}_{2}$ has no significant effect on the overall enzyme catalyzed reaction. In addition, it was observed that in the absence of this coadjutant there was no decolorization.

\subsubsection{Optimum concentration of dye}

The concentration of substarate is a key factor which affects the rate of the enzyme catalyzed oxidation.

Studies were carried out at different concentrations of the dye (10-60 $\left.\mathrm{mg} \mathrm{L}^{-1}\right)$, keeping all the other parameters constant $\left(\mathrm{H}_{2} \mathrm{O}_{2}\right.$ $100 \mu \mathrm{mol}^{-1}$; reaction time $50 \mathrm{~min}$; enzyme $10.83 \mathrm{U} \mathrm{mL}^{-1}$ ) and the results are shown in Fig. 4 . The increase in dye concentration until $40 \mathrm{mg} \mathrm{L}^{-1}$ provides an effective increase in color removal. Subsequent increase in dye concentration above $40 \mathrm{mg} \mathrm{L}^{-1}$ resulted in negligible dye removal. Mohan et al. [20] studied the enzymatic decolorization of the Acid Black 10BX dye by Horsehadish peroxidase (HPR) at different dye concentrations, and it was concluded that concentrations above $30 \mathrm{mg} \mathrm{L}^{-1}$ resulted in low efficiency of the decolorization.

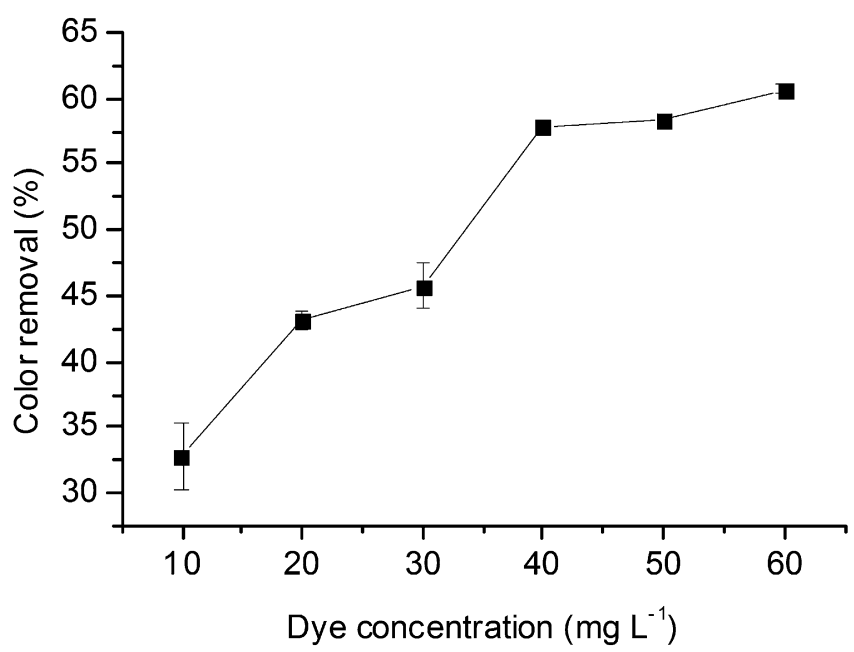

Fig. 4. Effect of the dye concentration on the decolorization of RB21 by turnip peroxidase. 

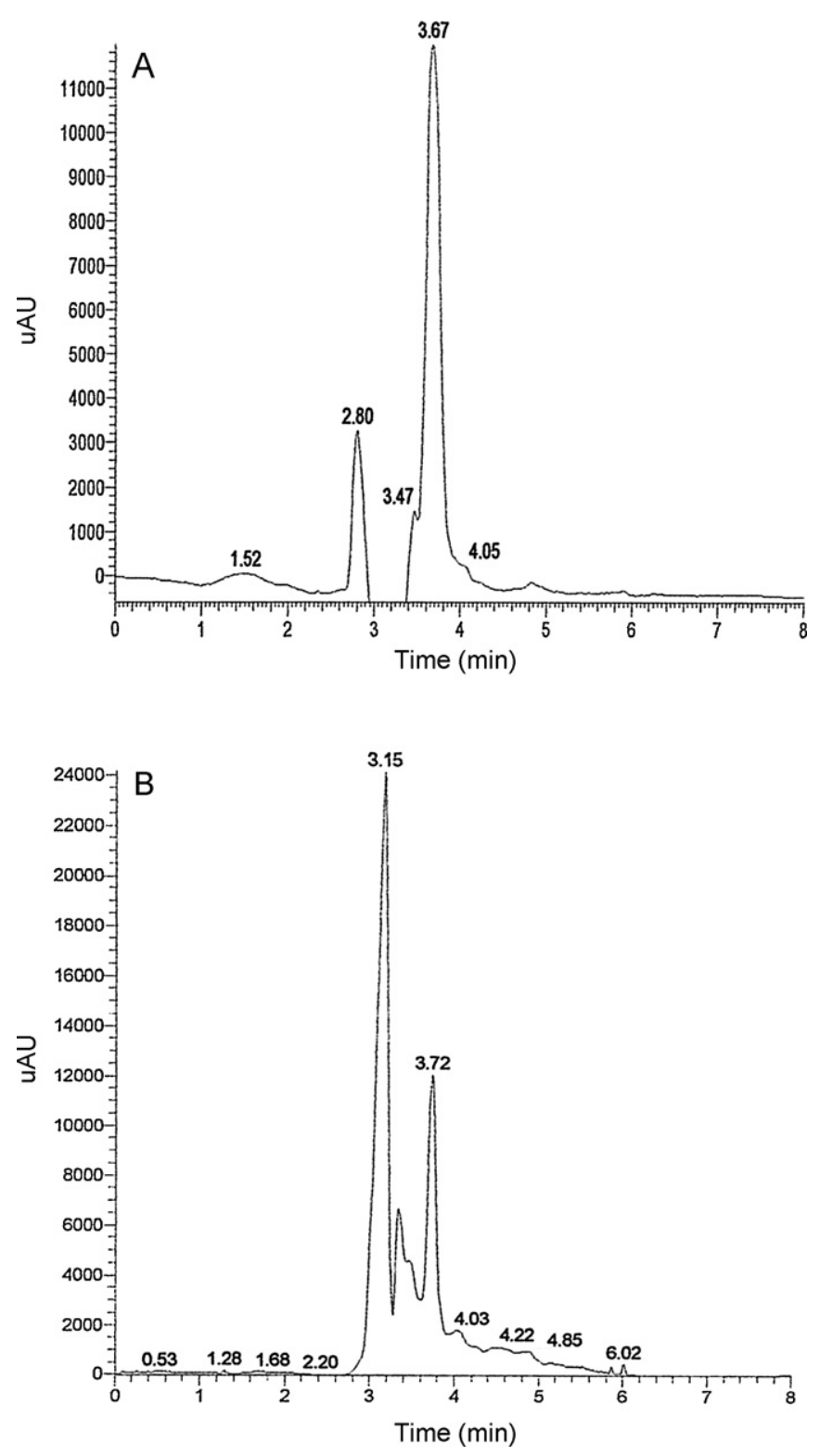

Fig. 5. HPLC chromatograph (a) control [dye] and (b) sample [treated dye].

\subsubsection{Optimum concentration of enzyme}

Normally the removal of the aromatic compound is dependent on the amount of catalyst added since the catalyst has a finite lifetime and also the conversion is found to be dependent on the contact time [20]. Within the enzyme concentrations evaluated $\left(1.26-26.16 \mathrm{UmL}^{-1}\right)$ it was observed that when the concentration studied was $10.83 \mathrm{U} \mathrm{mL}^{-1}$, the decolorization of the dye was $54.5 \pm 0.5 \%$; however, when the concentration increased approximately twice $\left(20.3 \mathrm{U} \mathrm{mL}^{-1}\right)$ the decolorization was $57.7 \pm 0.3 \%$. From these results, it was concluded that using a higher concentration of enzyme, there was a slight decrease on the decolorization of the dye. This observation is in agreement with the outcome presented by Forgiarini et al. [12] which studied the enzymatic decolorization of RB21 by HPR. The authors mentioned that a concentration of $14.885 \mathrm{U} \mathrm{mL}^{-1}$ corresponds to a decolorization of $58 \%$ and the multiplication of the concentration by two gave only a percentage of decolorization corresponding to $62 \%$.
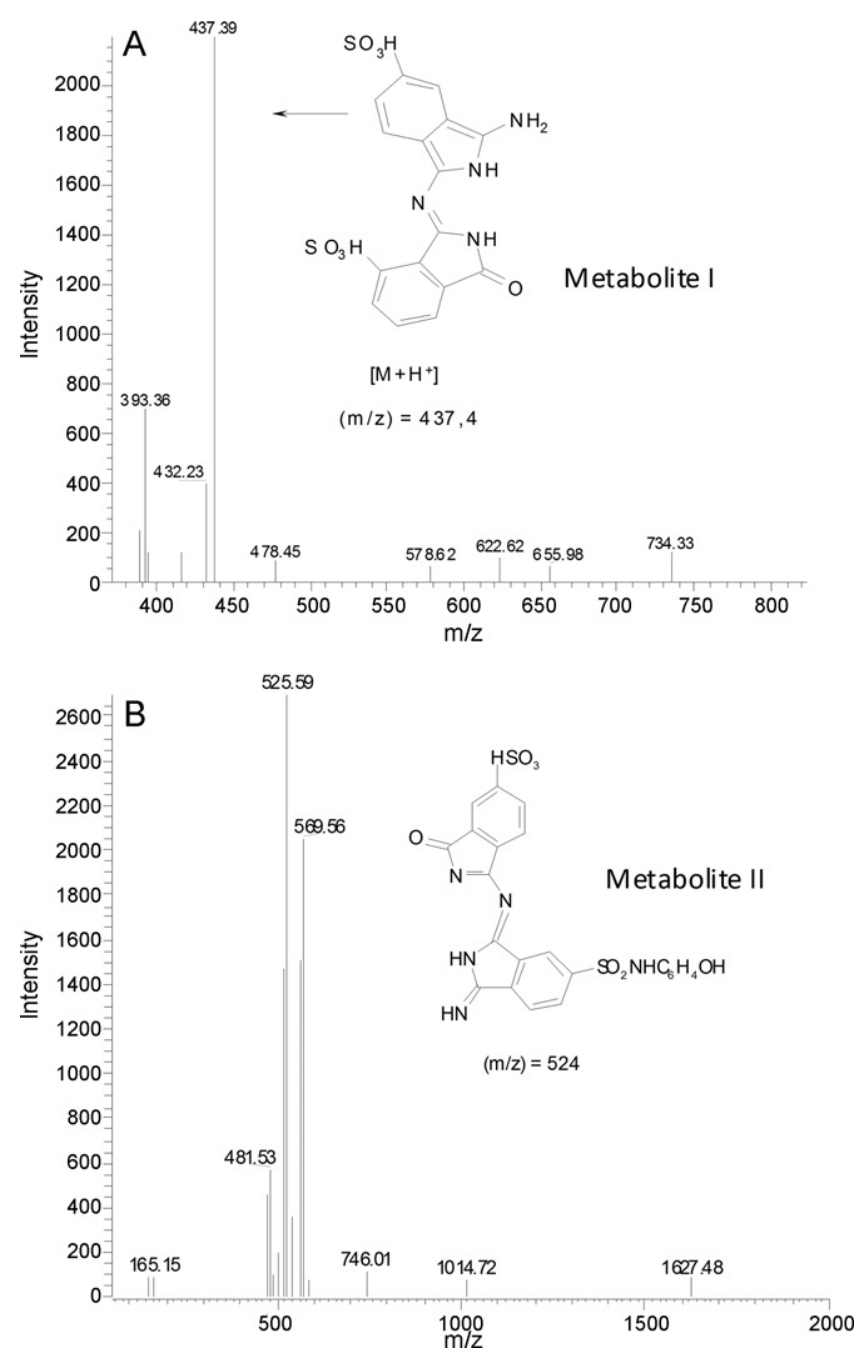

Fig. 6. Mass spectra of reaction products of RB21 incubated with turnip peroxidase obtained by LC-ESI/MS analysis.

\subsection{Formation and identification of metabolites}

In order to detect biodegradation intermediates or stable metabolites yielded during oxidation of the RB21 by turnip peroxidase, HPLC-DAD and LC-ESI/MS analysis were carried out simultaneously. HPLC-DAD profile on the control sample (dye without treatment) showed two peaks with retention times of 2.80 and 3.67 min respectively. After enzymatic treatment the chromatogram shows two important peaks with retention times of 3.15 and 3.72 respectively. The peak at $2.80 \mathrm{~min}$ corresponding to the control sample was not detected after enzymatic treatment (Fig. 5). These results indicate the possible breakdown of the parent molecule and the formation of the new products.

Chromatograms and mass spectra of the reaction products of RB21 incubated with turnip peroxidase are displayed in Fig. 6. Mass spectrometry data revealed at least 3 major products (Fig. 6), two of which were identified as metabolite I: $\mathrm{m} / \mathrm{z}=437$ and metabolite II: $\mathrm{m} / \mathrm{z}=524$ respectively.

Heinfling-Weidtmann et al. [24] studied the degradation products of reactive blue 15 and reactive blue 38 (phthalocyanine dyes) by the white-rot fungus $B$. adusta. Sulfophthalimides (SPI; 3 and 4) were identified as major metabolites by comparison with synthesized reference compounds and the release of $\mathrm{Cu}^{2+}$ from the metal complex was proposed. This outcome is supported by other 
Table 1

Percentages of inhibition on the growth of radicles of lettuce to the dye RB21 after treatment.

\begin{tabular}{|c|c|c|c|c|c|}
\hline \multirow[t]{2}{*}{ Treatments } & \multicolumn{4}{|c|}{ Concentration (\%) } & \multirow[t]{2}{*}{$\mathrm{LC}_{50}$} \\
\hline & 100 & 75 & 50 & 25 & \\
\hline Raw dye & $7.42 \pm 1.6$ & $0.0 \pm 0.0$ & $0.0 \pm 0.0$ & $0.0 \pm 0.0$ & - \\
\hline Dye treated & $61.50 \pm 2.3$ & $50.26 \pm 1.0$ & $30.3 \pm 4.9$ & $12.3 \pm 2.5$ & 74.60 \\
\hline
\end{tabular}

a Data are the mean of three replicates \pm standard deviation.

authors who also studied the decolorization of phthalocyanine dyes by white-rot fungi [11-25].

According to data reported in literature and mass spectra obtained, the structures of metabolites I and II were suggested. The major products formed involving cleavage of the nitrogen bonds in the inner ring of the phthalocyanine molecule and release of $\mathrm{Cu}^{2+}$ from the metal complex. As a result, the mechanism of the sulfophthalocyanine dye (RB21) degradation by turnip peroxidase was proposed (Fig. 7).

Probably, the discrepancy of one unit mass, related to metabolite II, is due to changes in side chain as the gain of protons for example. The metabolite II is probably a fragment related to the metabolite of $\mathrm{m} / \mathrm{z} 569.56$, whose structure was not identified. This fragmentation can occur due to oxidative changes also in the side chain.

\subsection{Acute toxicity test with L. sativa}

The toxicity study of the untreated dye and the dye after the enzymatic treatment was carried out with the purpose of evaluating the change of toxicity due to the treatment.

From the results shown in Table 1, the toxicity of the dye before and after enzymatic decolorization treatment, it can be observed that the non-treated dye shows lower toxicity. Therefore, it was not possible calculate the average lethal concentration ( $\left.\mathrm{LC}_{50}\right)$. However, after treatment the $\mathrm{LC}_{50}$ was $74.60 \%$. These results showed
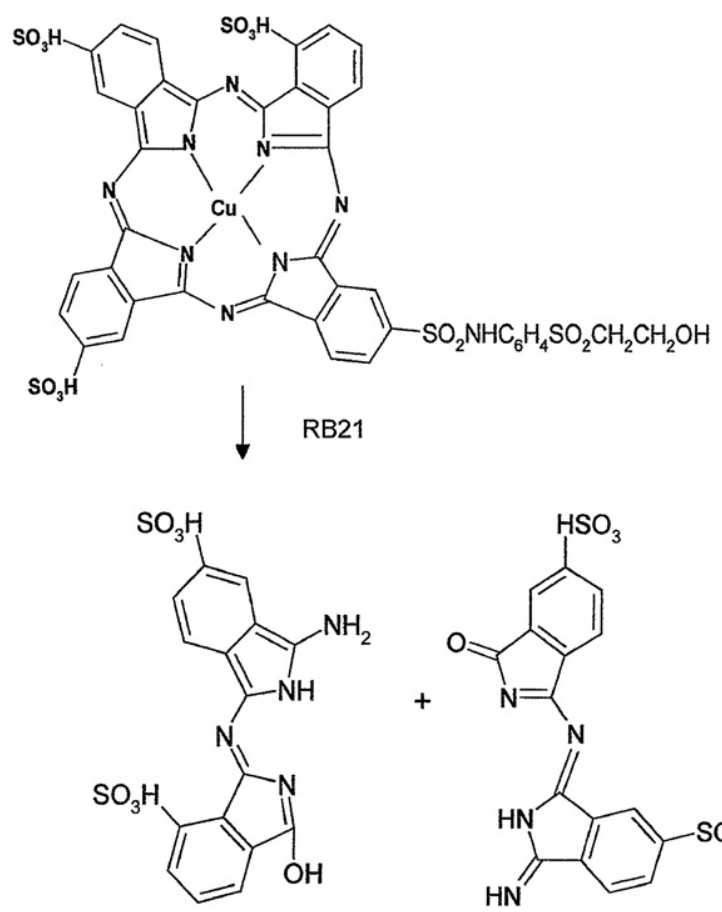

Metabolite I $(\mathrm{m} / \mathrm{z}=437)$

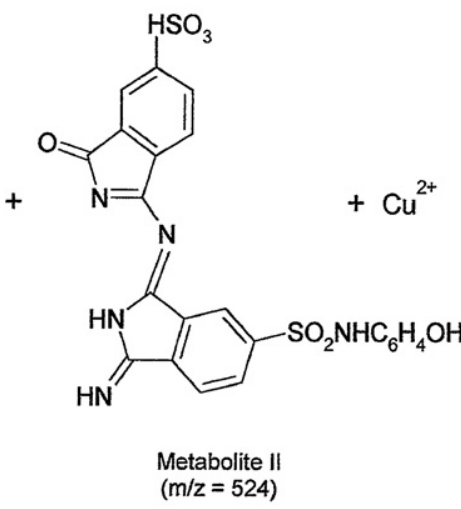

Fig. 7. Suggested scheme for the oxidative of the dye RB21 by turnip peroxidase. that after enzymatic treatment an increase of the toxicity was observed.

The increase of the toxicity after enzymatic treatment can be attributed to the presence of $\mathrm{Cu}^{2+}$ in solution, or to the formation of metabolites that are more toxic than the parent molecule.

Therefore, the acute toxicity test with $L$. sativa was also carried out using a $\mathrm{Cu}^{2+}$ solution at the concentration of $0.037 \mu \mathrm{mol} \mathrm{mL}{ }^{-1}$ $\left(\mathrm{Cu}^{2+}\right.$ content theoretical for $\mathrm{RB} 21$ dye at $\left.40 \mathrm{mg} \mathrm{L}^{-1}\right)$. The inhibition percentage of growth of lettuce's radicles obtained was $15.91 \pm 4.30 \%$. It was concluded that, in fact, the release of $\mathrm{Cu}^{2+}$ to the solution after enzymatic treatment contributes to increase of toxicity.

Similar results were observed by Kunz et al. [26], who obtained increase toxicity of the dye RB21, after treatment with ozone according to the release of copper from the dye structure. The removal of $\mathrm{Cu}^{2+}$ from the solution can be carried out using simple precipitation or by adsorption on activated clay and activated carbon [27].

These results emphasize the importance of toxicological evaluation after enzymatic treatment. Considering the potential application of enzymes for color removal and the present result where the metabolites formed are more toxic than parental molecule, the enzymatic treatment should be associated with another type of treatment.

In this case, the enzymatic treatment can be associated with microbial degradation, in which the enzyme break up the complex chemical structure of dye and the bacteria then mineralize a substantial portion of the breakdown products [27].

\section{Conclusions}

The results showed that reactive phthalocyanine dyes can be decolorized after incubation with turnip peroxidase. However, the degradation process efficiency seems to be dependent of parameters such as concentration of enzyme, dye and $\mathrm{H}_{2} \mathrm{O}_{2}$; reaction time.

LC-ESI/MS analysis showed that the decolorization of the dye RB21 by turnip peroxidase is due to the breaking up of the chromatogenous system.

The toxicity of the dye RB21 towards lettuce seeds increases after incubation with turnip peroxidase. This can be attributed to the presence of $\mathrm{Cu}^{2+}$ in solution, or due to formation of metabolites with higher toxicity. However, the toxicity of the dye can be removed by combination with other biologics process.

The enzymatic treatment may represent an important step for complete microbial degradation of textile dyes, especially those classified as phthalocyanines.

\section{Acknowledgements}

The authors would like to acknowledge FAPEMIG, CNPq, CAPES for supporting this work.

\section{References}

[1] R.M. Dallago, A. Smaniotto, L.C.A. De Oliveira, Quim. Nova 28 (2005) 433-437. [2] E. Forgacs, T. Cserháti, G. Oros, Environ. Int. 30 (2004) 953-971. 
[3] J.R. Aspland, Textile Dyeing an Coloration, American Association of Textile Chemists and Colorists, Research Triangle, Park, NC, 1997.

[4] R.D. Mathews, L.A.S.G. Bottomley, P. Pavlostathis, Desalination 248 (2009) $816-825$.

[5] V.V. Kumar, V. Sathyaselvabala, M.P. Premkumar, T. Vidyadevi, S. Sivanesan, J. Mol. Catal. B: Enzym. (2011), doi:10.1016/j.molcatb.2011.08.015.

[6] A. Heinfling, M.J. Martínez, A.T. Martínez, M. Bergbauer, U. Szewzyk, Appl. Environ. Microbiol. 64 (1998) 2788-2793.

[7] Q. Husain, Crit. Rev. Biotechnol. 26 (2006) 201-221.

[8] C.I. Guaratini, M.V.B. Zanoni, Quim. Nova 23 (2000) 71-78.

[9] A. Kunz, P. Peralta-Zamora, S.G. Moraes, N. Durán, Quim. Nova 3 (2002) 78-82.

[10] Q. Hussain, Rev. Environ. Sci. Biotechnol. 9 (2009) 117-140.

[11] A. Heinfling, M.J. Martínez, A.T. Martínez, M. Bergbauer, U. Szewzyk, FEMS Microbiol. Lett. 165 (1998) 43-50.

[12] S.M.A.G.U. Souza, E. Forgiarini, A.A.U. Souza, J. Hazard. Mater. 147 (2007) 1073-1078.

[13] T. Marchis, P. Avetta, A. Bianco-Prevot, D. Fabbri, G. Viscardi, E. Laurenti, J. Inorg. Biochem. 105 (2011) 321-327.

[14] T. Kusui, C. Blaise, Impact Assessment of Hazardous Aquatic Contaminants, S.S. Rao, Ann Arbor Press, Michigan, 1999, p. 161.
[15] S.B. Jadhav, S.S. Phugare, S.P. Patil, J.P. Jadhav, Int. Biodeter. Biodegrad. 65 (2011) 733-743.

[16] M.R. Da Silva, L.R.V. De Sá, C. Russo, E. Scio, V.S. Ferreira-Leitão, Enzyme Res. (2010), doi:10.4061/2010/703824.

[17] A. Connelly, S. Mcclean, W.F Smyth, G. Mcmullan, Rapid Commun. Mass Spectrom. 15 (2001) 2076-2084.

[18] O. Fatibello-Filho, I. Vieira, Quím. Nova 25 (2002) 455-464.

[19] A.A Khan, D.S. Robinson, Food Chem. 49 (1994) 407-410.

[20] S.V. Mohan, K.K. Prasad, N.C. Rao, P.N. Sarma, Chemosphere 58 (2005) 1097-1105.

[21] B. Dutkka, Short-Term Root Elongation Toxicity Biossay. Methods for Toxicological Analysis of Waters, Wastewaters and Sediments, National Water Research Institute, Ottawa, 1989.

[22] J. Wu, J.K. Bewtra, N. Biswas, K. Taylor, Can. J. Chem. Eng. 72 (1994) 881-886.

[23] V.S. Ferreira-Leitão, J.G. Silva, E.P.S. Bon, Appl. Catal. B 42 (2003) 213-221.

[24] A. Heinfling-Weidtmann, T. Reemtsma, T. Storm, U. Szewzyk, FEMS Microbiol. Lett. 203 (2001) 179-183.

[25] A.W. Conneely, F. Smyth, G. McMullan, Anal. Chim. Acta 451 (2002) $259-270$.

[26] A.A. Kunz, H. Mansilla, N. Duran, Environ. Technol. 23 (2002) 911-918.

[27] T. Vengris, R. Binkiene, A. Sveikauskaite, Science 18 (2001) 183-190. 